\title{
Review of Shahzavar Karimzadi's Money and its origins. London: Routledge, 2012, 268 pp.
}

\author{
GEORGIOS PAPADOPOULOS
}

Aarhus University

Erasmus University Rotterdam

A fascinating subject can make a great book, and money is one of the topics that have captured the public mind and the intellectual interest of philosophers and scientists alike. The recent financial collapse (circa 2008), and particularly its reverberations in the European Union, has energized the debate around money and led to a new wave of publications of books and articles on the subject. The question of the origin of money may not seem directly relevant to the troubles of the Eurozone but it remains important and relatively neglected. The detailed analysis of Shahzavar Karimzadi's book certainly fills the gap, and also has something to contribute to contemporary debate about monetary policy.

The book is an exposition and a critique of the different accounts of the origin of money, and the definitions of money that are related to them. Karimzadi examines a long list of candidate explanations for the passage from a moneyless to a moneyed economy, usually based on a single causal mechanism associated with barter exchange and its limitations (the division of labor, surplus production, exchange, degrees of marketability), and finds them all wanting. Karimzadi argues, rightly I think, that a system of pure barter is a convenient fiction invented to support an account that has remained relatively unchanged since the time of Aristotle, and that in any case the limitations of barter alone cannot explain the origin of money. He goes on to argue that each and every candidate explanation is illuminating but partial, and cannot alone account for the origin of money. Karimzadi is also skeptical of the definitions that support the different accounts, which privilege a specific function or 'form' of money, because he finds them too restrictive to describe money in all its complexity and mutability. If one declares that money is defined by its function as a means of exchange and proceeds to offer an analysis of its origin in those terms, such an 
analysis will necessarily be incomplete, since it leaves out other 'forms' of money.

The book itself does not come to an explicit conclusion about the proper definition of money, though the author seems sympathetic, up to a point, to the Marxist description of money as universal equivalent. Nor does Karimzadi privilege any one explanation of the origins of money, but prefers to write a more complex story that aggregates different instances of the emergence of money, which are connected to the various forms and functions that money has served in different historical contexts. The author prefers, in lieu of a conclusion, to compile an aggregating explanation of the origin of money and of its definition, where a variety of causes for its origin are enumerated and connected with different descriptions of what money is and does.

The mainstream commodity theory features extensively, with all its minor variations and particularities. The book traces the intellectual history of this account from the time of Aristotle to more recent incarnations relating to barter exchange, including its representation in economics textbooks since Alfred Marshall. Yet if one looks at Karimzadi's bibliography, the relative neglect of contemporary scientific articles on the subject is striking. Recent formal work by commodity theorists on the emergence of money, and their methodology, is not really considered. Karimzadi may assume, justifiably I think, that such recent accounts suffer from some of the same fundamental flaws that he ascribes to all the mainstream accounts of the origin of money: a commitment to the fiction of barter and to a clear-cut distinction between barter and monetary exchange, as well as a one-dimensionalfunctionalist-definition of money as a means of exchange. Still, work in economics (e.g., Alchian 1977; Jones 1976; Kiyotaki and Wright 1989), and more recently in philosophy (e.g., Aydinonat 2008; Tieffenbach 2010; Smit, et al. 2011), has provided new insights into the mechanisms behind the emergence of money by offering rational reconstructions of its origins in individual attitudes and behavior that are comparable to what Karimzadi does when he presents his own account in the final chapter of his book. Discussing such research, and perhaps juxtaposing it with the author's own account of the origin of money, could have been very useful and informative to the reader.

Karimzadi's proclaimed methodology is an even greater problem than the lack of contemporary references. In the part of the introduction entitled "Method of Inquiry", Karimzadi introduces Hume's account 
of the problem of induction as an obstacle to an empirical resolution of the debate about the origin of money. But the problem of induction is irrelevant to the accounts the author evaluates. There may be some references to historical, anthropological, or even anecdotal evidence, but these are mere illustrations. The main burden of the argument is carried by verbal or formal reasoning. From Carl Menger (1892) to the recent reformulations of equilibrium explanations by Nabuhiro Kiyotaki and Randall Wright $(1989 ; 1991 ; 1993)$ or Dan Kovenock and Caspar De Vries (2002) the issue of empirical evidence has never been part of the analysis of the emergence of money in mainstream economics. This point is of some historical significance. The nineteenth century academic debate over the origins of money between commodity theorists and state theorists from the historical school led to the Methodenstreit that established the deductive method combined with methodological individualism as the methodology of choice for mainstream economics. It is therefore a big distortion of the history of economic thought and of the theories of money discussed to introduce the problem of induction. Moreover, Hume's problem of induction does not seem very relevant to the question of the origin of money anywayHume was more concerned with law-like universal generalizations and their underdetermination by evidence than with the emergence of social facts, like money.

I am very sympathetic to Karimzadi's criticisms of the mainstream 'commodity' accounts of money, but I think that they fall short of a convincing argument for discarding such accounts altogether. Obviously, Karimzadi goes into some detail to explain the flaws in the accounts he criticizes, and the exposition that unfolds in the book is informative. But I believe that what economic theory has been concerned with in relation to money is not to provide an account of its actual historical origin, but rather to provide the logical structure of the emergence and the persistence of money in a market setting based on its function or functions.

There is thus no contradiction in relating the function of money to its emergence and it is not clear what the author means when he argues against functionalist accounts of the origin of money on the grounds that it is methodologically flawed to derive the origin of money from its form. Functional explanation is a legitimate, and probably the most common, type of explanation in the social sciences. Economists' functional analysis of the emergence of money is supported by invisible 
hand arguments that add a positive feedback effect between the function of money as a means of exchange and its establishment. Both the commodity and the state theories of money attempt a rational reconstruction of the origin of money that is supportive of their definitions. These definitions are underlined by a 'natural selection' argument in which money is supposed to be selected to fulfill the specific economic functions that define it and are considered to be the reason for its existence.

The book's critique of the state theory of money is also problematic. Karimzadi is obviously correct when he argues that money precedes the state, ${ }^{1}$ and in that sense it is wrong to argue that the state is the origin of money. But, as the author himself admits, the state theory refers to the emergence of modern fiat money (p. 210). The core of this theory is the dependence of money on a sovereign authority that represents the community and enforces a standard of value and taxation, and the reliance of money on power is equally true for modern and primitive societies. The organization of social relations in terms of indebtedness suggests that the very act of valuation and the concept of value predate the market. The primordial measures of compensation for damages, such as Wergeld or 'honorable payment', are the predecessors of economic value, and the first incarnation of money (Ingham 2004, 92). The origin of economic valuation in Wergeld is not just an historical fact, but also a mechanism that can explain the origin of money. The organization of a system of economic compensation for injuries constitutes a shared system of social valuations that anticipates the system of prices. The important difference with the commodity theory is that the system of valuation is not the outcome of bilateral exchanges, but the imposition of a cardinal taxonomy by authority. The significance of Wergeld and its dependence on authority provides a foundation for the state theory of money and its narrative about the origin of money that goes beyond the limitations of barter.

The book offers an intellectual history of the origin of money, which is interesting and detailed, accompanied by a critique and an alternative pluralistic conception of money and its origin Nevertheless, the author fails to incorporate the most recent work on the subject by philosophers and economists. In addition, the critique often misses the mark, partly

\footnotetext{
${ }^{1}$ Still Karimzadi's chronology of the different types of "debt-economies" (p. 204) is not accurate. Individual debt to the community is part of the social bond and predates the emergence of money (Graeber 2011).
} 
because the author works from the wrong methodological premises and partly because he fails to recognize that what is really at stake in mainstream economics is to explain the emergence, the persistence, and the acceptability - or the value-of money in the context of a market economy. Strictly speaking, the question of the origin of money falls outside the subject matter of economics or of philosophy. These two disciplines can illuminate mechanisms that underlie the emergence of money, but they require the support of anthropology and history to establish the truth of their stories (Pryor 1977).

\section{REFERENCES}

Alchian, Armen. 1977. Why money? Journal of Money, Credit, and Banking, 9 (1): 133140.

Aydinonat, N. Emrah. 2008. The invisible hand in economics: how economists explain unintended social consequences. London: Routledge.

Graeber, David. 2011. Debt: the first 5,000 Years. New York: Melville House Publishing. Ingahm, Geoffrey. 2004. The nature of money. London: Polity.

Jones, Robert A. 1976. The origin and development of media of exchange. Journal of Political Economy, 84 (4): 757-775.

Kiyotaki, Nobuhiro, and Randall Wright. 1989. On money as a medium of exchange. Journal of Political Economy, 97 (4): 927-954.

Kiyotaki, Nobuhiro, and Randall Wright.1991. A contribution to the pure theory of money. Journal of Economic Theory, 53 (2): 215-235.

Kiyotaki, Nobuhiro, and Randall Wright. 1993. A search theoretic approach to the pure theory of money. American Economic Review, 83 (1): 63-77.

Kovenock, Dan, and Casper De Vries. 2002. Fiat exchange in finite economies. Economic Inquiry, 40 (2): 147-157.

Menger, Carl. 1892. On the origin of money. The Economic Journal, 2 (6): 239-255.

Pryor, Frederic L. 1977. The origins of money. Journal of Money, Credit, and Banking, 9 (3): 391-409.

Smit, J. P., Filip Buekens, and Stan du Plessis. 2011. What is money? An alternative to Searle's institutional facts. Economics and Philosophy, 27 (1): 1-22.

Tieffenbach, Emma. 2010. Searle and Menger on money. Philosophy of the Social Sciences, 40 (2): 191-212.

Georgios Papadopoulos is a $\mathrm{PhD}$ candidate at Erasmus University Rotterdam and works as a research assistant at Aarhus University.

Contact email: <languagegames@gmail.com> 